This document is published in:

Actas Dermo-Sifiliográficas, Vol. 103, no 1, pp. 5-11

DOI: http://doi.org/10.1016/j.adengl.2011.03.016

(c) 2012 Elsevier España. 


\title{
Skin Bioengineering: Preclinical and Clinical Applications
}

\author{
L. Martínez-Santamaría, ${ }^{a}$ S. Guerrero-Aspizua, ${ }^{b}$ M. Del Río ${ }^{a, b, *}$ \\ a Unidad de Medicina Regenerativa, Departamento de Investigación Básica, División de Biomedicina Epitelial, Centro de \\ Investigaciones Energéticas, Medioambientales y Tecnológicas (CIEMAT) y Centro de Investigación Biomédica en Red de \\ Enfermedades Raras (CIBERER), Madrid, Spain \\ b Departamento de Bioingeniería, Universidad Carlos III (UC3 M), Madrid, Spain
}

\section{KEYWORDS}

Tissue engineering;

Regenerative

medicine;

Stem cells;

Humanized mouse

models of skin

diseases;

Experimental

dermatology

\section{PALABRAS CLAVE}

Ingeniería de tejidos;

Medicina

regenerativa;

Células madre;

Modelos humanizados

de enfermedades

cutáneas;

Dermatología

experimental
Abstract Regenerative Medicine is an emerging field that combines basic research and clinical observations in order to identify the elements required to replace damaged tissues and organs in vivo and to stimulate the body's intrinsic regenerative capacity. Great benefits are expected in this field as researchers take advantage of the potential regenerative properties of both embryonic and adult stem cells, and more recently, of induced pluripotent stem cells. Bioengineered skin emerged mainly in response to a critical need for early permanent coverage of extensive burns. Later this technology was also applied to the treatment of chronic ulcers. Our group has established a humanized mouse model of skin grafting that involves the use of bioengineered human skin in immunodeficient mice. This model is suitable for the study of physiologic and pathologic cutaneous processes and the evaluation of treatment strategies for skin diseases, including protocols for gene and cell therapy and tissue engineering.

\section{Bioingeniería cutánea: aplicaciones preclínicas y clínicas}

Resumen La Medicina Regenerativa es un campo emergente que combina la investigación básica y la experiencia clínica con el objetivo de proporcionar los elementos necesarios para reemplazar in vivo tejidos y órganos dañados, estimulando además la capacidad regenerativa intrínseca del organismo. Se esperan grandes avances en este campo en los próximos años, debido a las potenciales propiedades regenerativas de las células madre embrionarias y adultas, y más recientemente de las células madre pluripotentes inducidas.

La bioingeniería cutánea surgió motivada principalmente por la necesidad crítica de dar cobertura permanente a grandes quemados, y posteriormente se ha empleado también en el tratamiento de úlceras crónicas. Nuestro equipo ha desarrollado un modelo preclínico humanizado basado en el trasplante de piel bioingenierizada a ratones inmunodeficientes que posibilita

\footnotetext{
* Corresponding author.

E-mail address: marcela.delrio@ciemat.es (M. Del Río).
} 
el estudio de procesos fisiológicos y patológicos cutáneos, así como la evaluación de estrategias terapéuticas de intervención dermatológica, incluyendo protocolos de terapia génica y celular e ingeniería tisular.

\section{Introduction}

The epidermis regenerates continuously through the proliferation of the epidermal stem cells, a subpopulation of specialized cells in the basal layer. ${ }^{1}$ An understanding of basic epidermal stem cell biology and the mechanisms governing the multipotency of these cells, together with an understanding of the genetic basis of various skin diseases, are crucial components in the development of possible therapeutic strategies for clinical application. In fact, the success of the most novel skin tissue engineering therapies based on gene and cell therapy protocols is largely due to the fact that they have managed to ensure that the stem cell compartment retains its function. Over the past 15 years, great strides have been made in the identification, isolation, and characterization of epidermal stem cells. ${ }^{2,3}$
The possible therapeutic use of somatic cells derived from embryonic stem cells is currently a hot topic in regenerative medicine. Although skin biopsies are a regular source of keratinocytes and epidermal stem cells, recent research suggests that the generation of keratinocytes from human embryonic stem cells could be a useful technique. ${ }^{4}$ Researchers have also managed to derive pluripotent cells from adult keratinocytes. ${ }^{5}$ Advances in this area have been truly breathtaking, and the challenge in the coming years will be to actually transfer all these breakthroughs in molecular biology to routine clinical practice.

\section{Skin Bioengineering in Clinical Practice}

To date, the standard treatment for severe and extensive burns is autografting, a technique based on grafting healthy

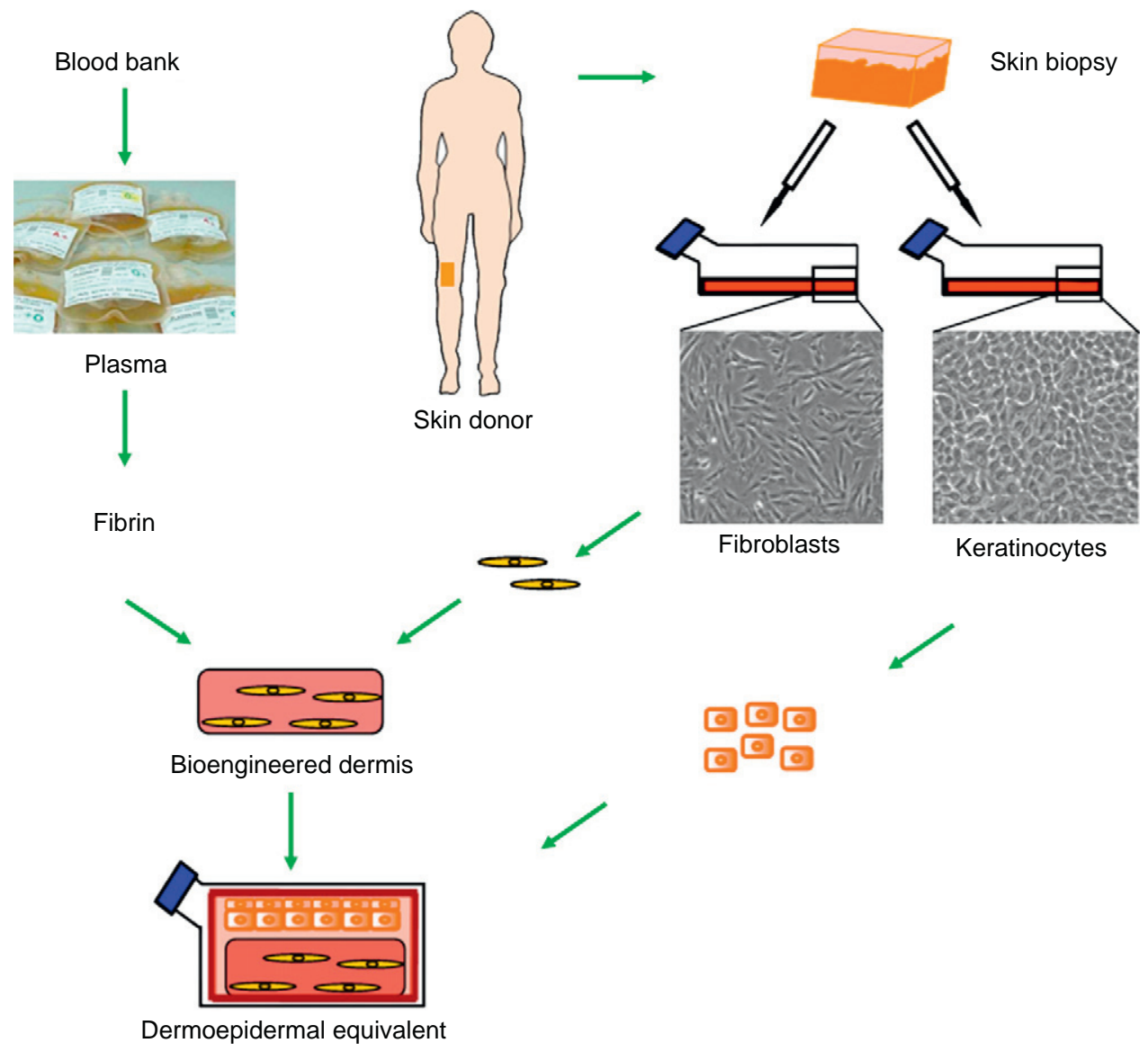

Figure 1 Generation of human dermoepidermal equivalents. Fibroblasts and keratinocytes obtained from donor skin biopsies are cultured. The fibroblasts are then arranged on a three-dimensional matrix rich in fibrin obtained from blood plasma. The keratinocytes are then seeded onto this artificial bioengineered dermis to form the epidermal component. 


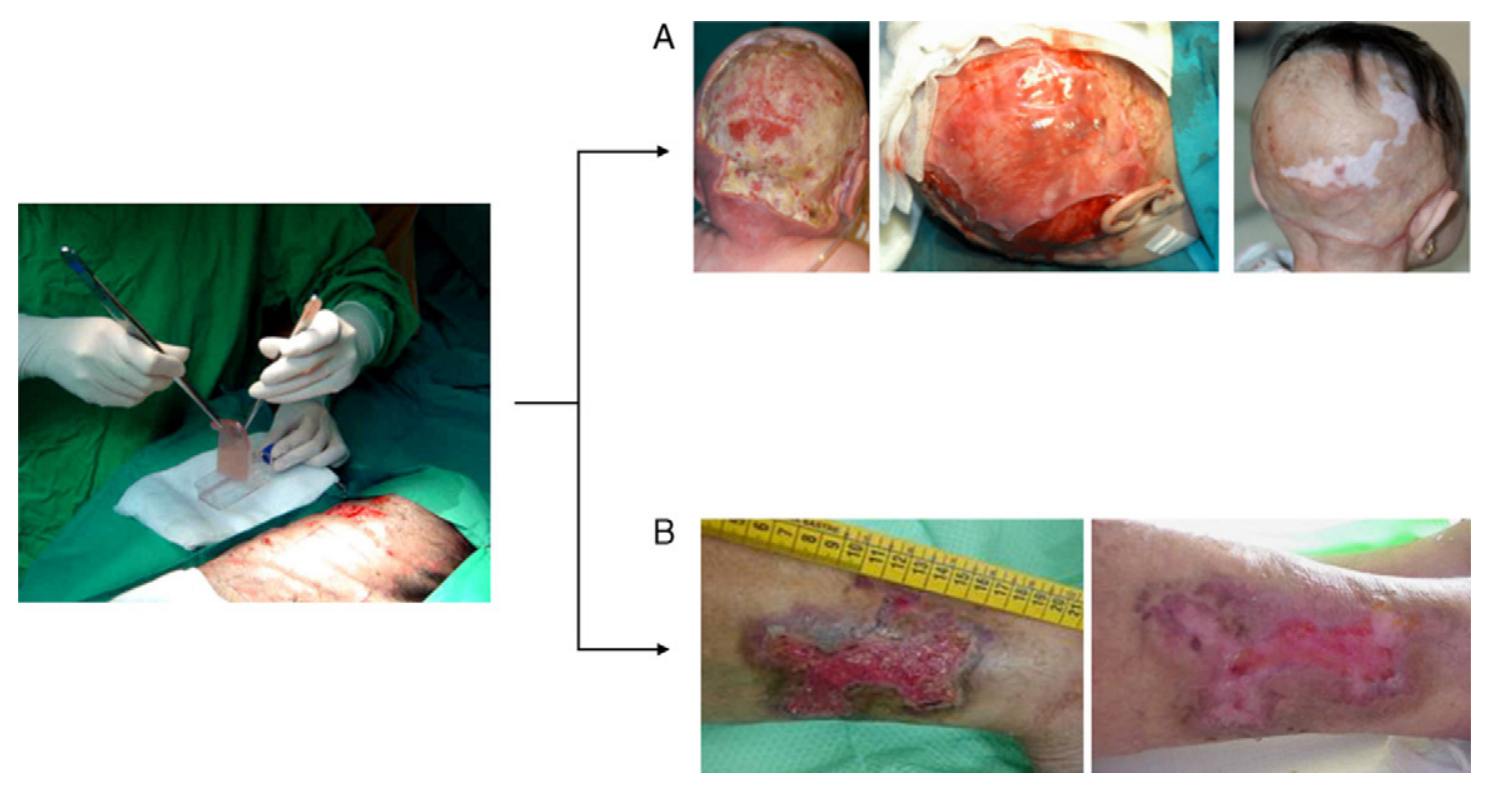

Figure 2 Clinical application of tissue-engineered skin equivalents for permanent regeneration in the treatment of (A) necrotizing fasciitis (images courtesy of Dr. Enriquez de Salamanca) and (B) for the temporary coverage of chronic ulcers.

skin from an uninjured area of the patient's own body to achieve permanent regeneration of the skin. ${ }^{6,7}$ This strategy is effective if the damage is not too extensive and there is enough undamaged skin available. Autografts are usually taken several times from the same area after allowing the donor site sufficient time to regenerate. The procedure is slow, painful, and difficult to perform in patients with burns affecting over $50 \%$ to $60 \%$ of the body surface area. The crucial importance of achieving permanent skin cover in this setting has led to the development of bioengineered skin, which offers an effective alternative to autografts. This approach also avoids the pain involved in graft harvesting, possible donor-site complications, and the problem of finding a sufficiently large area of healthy skin on the patient's own body. Thus, different types of bioengineered skin have been developed over the past 20 years. Although these skin substitutes were initially used as a solution for acute skin loss, they have subsequently been used in various applications, including the treatment of chronic wounds. ${ }^{8}$ The ideal skin substitute would be an easy-to-handle, durable, and inexpensive equivalent that can mimic the physiology of normal skin and not induce an immune rejection by the host. In general, the 3 key elements in skin bioengineering are (a) the cell source, (b) the regenerative capacity of the cells, and (c) the matrix or scaffold used. ${ }^{9}$ Early skin substitutes were composed solely of sheets of keratinocytes, until it was established that the inclusion of a biological template or scaffold that would act as connective tissue could improve the mechanical strength of the substitute, reduce scarring and, above all, favor the persistence of functional epidermal stem cells in vitro and in vivo. ${ }^{10-13}$

Although the perfect skin substitute has not yet been developed, our team has developed a dermoepidermal equivalent that has many of the desired characteristics and has proven clinically useful for skin regeneration. ${ }^{13-15}$ This bioengineered skin consists of a dermis composed of viable human fibroblasts seeded with keratinocytes, which form the epidermal layer (Fig. 1). Of particular interest is the use of a three-dimensional fibrin scaffold into which the fibroblasts are embedded. This fibrin matrix, which is also rich in growth factors and cytokines, artificially reproduces the normal healing process in vitro. After tissue damage, a temporary fibrin matrix is laid down that triggers damage repair through the migration of epithelial and mesenchymal cells to the site. Thus, fibrin is not only a reservoir of different factors but also provides an appropriate three-dimensional scaffold that promotes the migration, proliferation, and differentiation of cells in the wound bed. ${ }^{13,16}$ Similarly, the human dermal fibroblasts in the matrix strongly induce keratinocyte proliferation, making it possible to dispense with the use of coadjuvant mouse cells (a feeder layer). ${ }^{14}$ This method reduces the initial skin surface required to generate large areas of skin substitute for grafting because only very low densities of seeded keratinocytes are required. Furthermore, the optimum resistance and mechanical stability conferred by the fibrin matrix facilitates both the transport of these skin substitutes and their handling during the procedure.

All of these properties are very different from those of other biomaterials, such as collagen, which is used in various dermal equivalents, for example Apligraf. ${ }^{17}$ Unlike fibrin and coagulated plasma, materials based on the collagen matrix, which has the properties of quiescent skin, do not trigger the regeneration process. Consequently, collagen-based products must be seeded with keratinocytes at densities close to confluence.

The skin equivalent developed by our team has been used successfully in clinical applications. The autologous version has been used to achieve permanent tissue regeneration in various situations (major burns, necrotizing fasciitis, wound closure following resection of giant nevus, and in graft-versus-host disease). ${ }^{13,15,18}$ An allogeneic version has been used in the treatment of chronic ulcers (Fig. 2). ${ }^{19}$ The treatment of chronic ulcers has become important in 

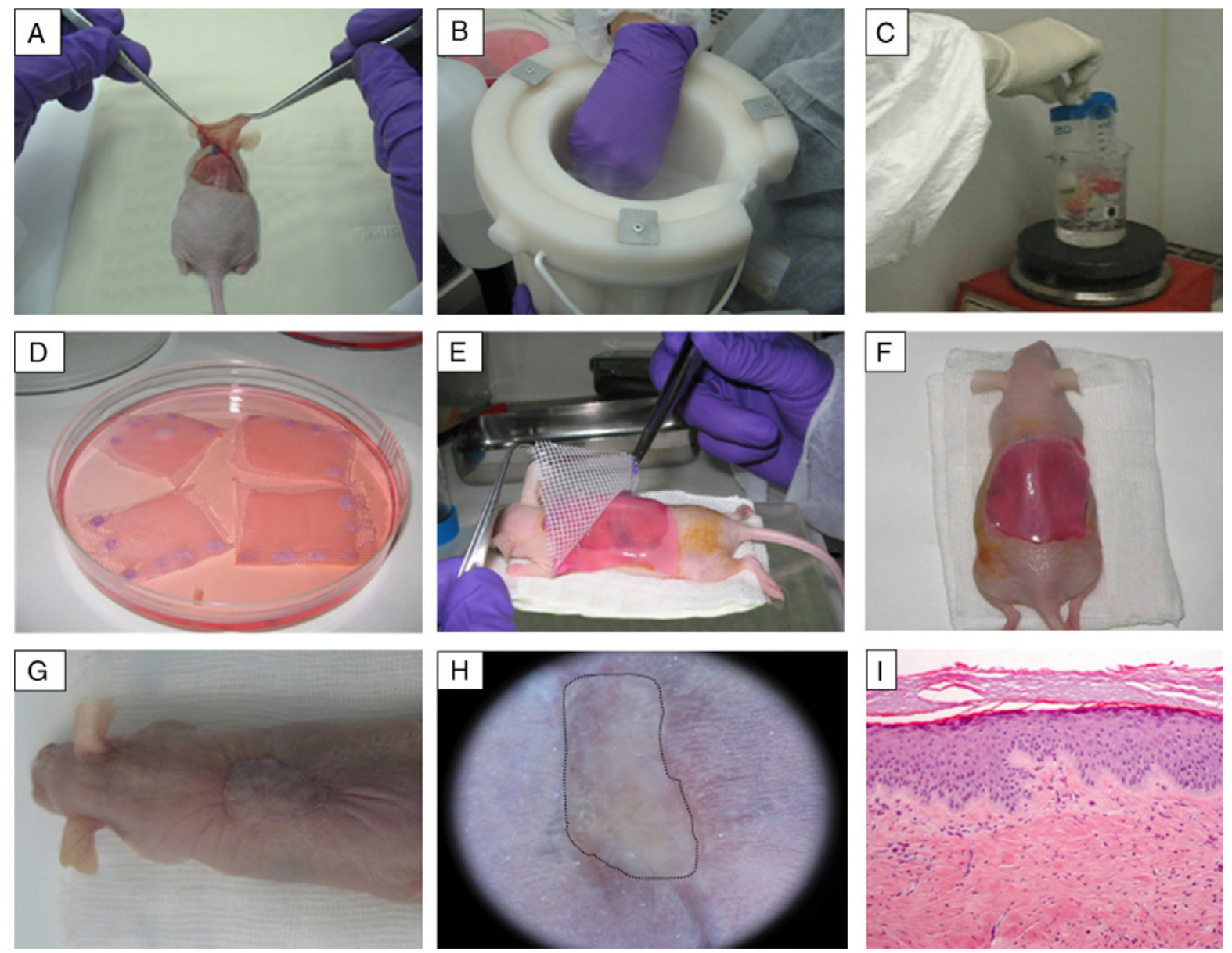

Figure 3 Generation of a skin-humanized mouse model. (A-C) The skin obtained from the wound made on the back of the anesthetized animal is devitalized by cycles of freezing in liquid nitrogen and thawing by immersion in boiling water. This devitalized skin is later fixed in place over the dermoepidermal equivalent to serve as a biological dressing that will protect the skin equivalent during the grafting process and will slough off naturally in approximately 2-3 weeks. (D-H) The dermoepidermal equivalent is orthotopically transplanted onto the wound created. (G-I) After 14 weeks, the images show the appearance of mice bearing regenerated human skin (delimited by dots), which is clinically and histologically distinct from murine skin (hematoxylin-eosin, $\times 10)$.

recent decades owing to the increase in life expectancy in the industrialized world and the associated increase in the prevalence of comorbid conditions, such as diabetes and vascular disease. The existence of a potential market amounting to some $2.1 \%$ of the total population of developed countries has motivated the design of various cell-based products with potential clinical benefits. ${ }^{20}$

\section{Preclinical Applications of Skin Bioengineering: The Development of a Skin-Humanized Mouse Model}

The skin-humanized mouse model developed in our laboratory is based on transplanting dermoepidermal equivalents generated using tissue engineering methods from donor fibroblasts and keratinocytes expanded in vitro (Fig. 3). The regenerated human skin recapitulates the main architectural and functional characteristics of natural human skin. ${ }^{21}$ The persistence of the transplanted skin for a period longer than the replacement cycle of the epidermis under physiological conditions (approximately 4 weeks) and the correct differentiation of the epidermal layers are evidence that epidermal stem cell function is preserved in vivo in the human skin regenerated on the mice. ${ }^{22}$ The main advantages of this model are the homogeneity achieved and the ability to produce a large number of animals bearing a significant area of human skin regenerated at a stable rate from a small biopsy taken from a single donor. ${ }^{23}$ The use of bioengineered skin for grafts has led to the development of humanized models to facilitate the study of a number of physiological skin processes, including wound healing. The in vivo system faithfully reproduces the functional and structural characteristics of the human healing process. This has been demonstrated through the analysis of a wide variety of parameters, such as cell proliferation, re-epithelialization, epidermal differentiation, dermal remodeling, and basement membrane reorganization. ${ }^{24}$ The model has also proved to be a valuable preclinical platform for evaluating cell and gene therapies in the field of dermatology in general and tissue regeneration in particular. ${ }^{18,25-27}$ Moreover, the system can be based on the patient's own cells. Thus, after 
A

Patient with RDEB

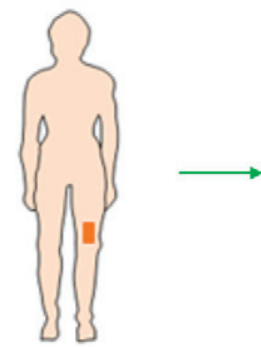

B

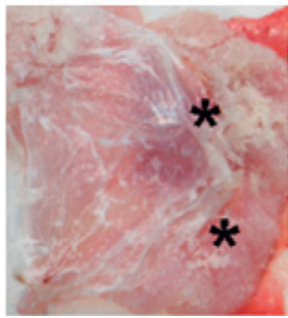

Skin biopsy

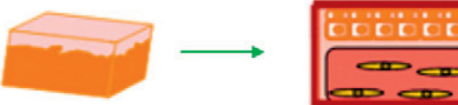

Bioengineered RDEB skin
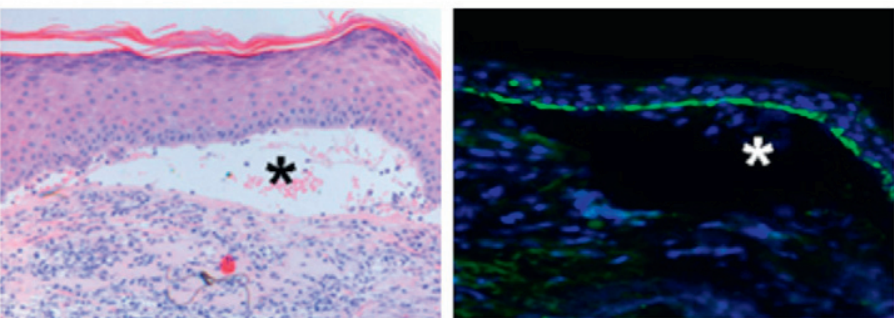

Figure 4 Development of humanized models of rare skin diseases. (A) Human skin regenerated in immunodeficient mice from cells obtained from patients with recessive dystrophic epidermolysis bullosa (RDEB) reproduces the phenotype of this severe disease (B) as evidenced clinically and histologically by the presence of blisters (hematoxylin-eosin, $\times 20$ ) (as indicated by asterisks) and the presence of type VII collagen in the roof of the blisters (type VII collagen, $\times 20$ ).

A

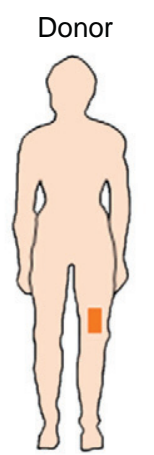

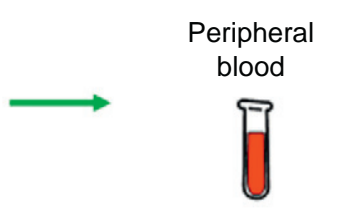

Skin biopsy

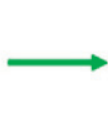

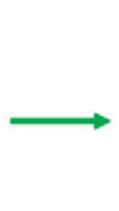

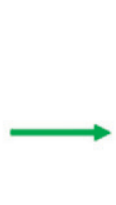

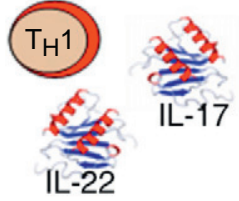

Bioengineered skin

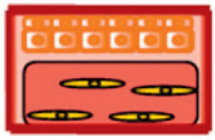

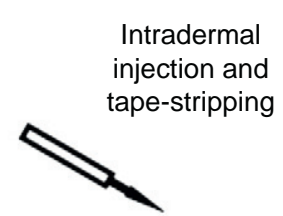

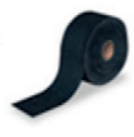

Skin-humanized mouse

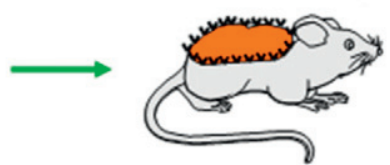

B Humanized psoriasis model

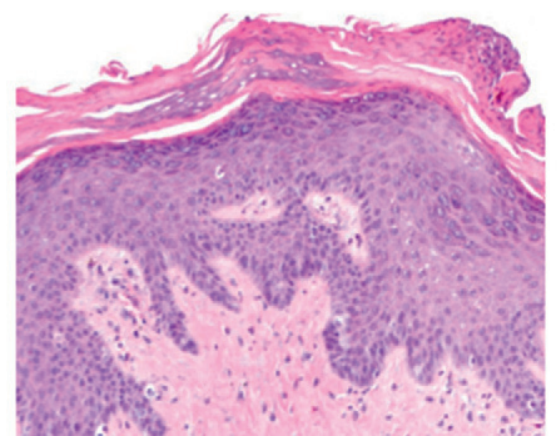

Patient with psoriasis

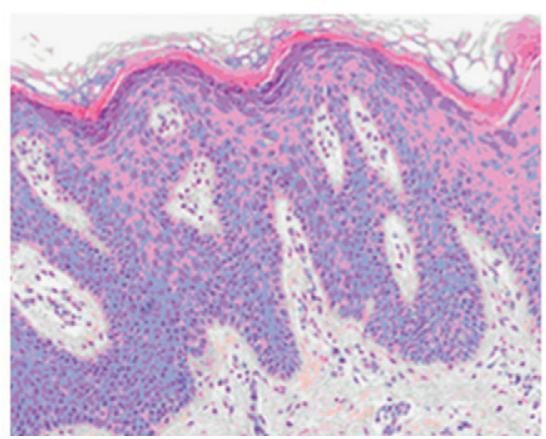

Figure 5 Modeling of prevalent skin diseases. (A) Humanized model of psoriasis based on intradermal injection in regenerated human skin of subpopulations of T-cells differentiated from a T 1 phenotype by the injection of $\mathrm{T}_{H} 17$ type cytokines (IL-17 and IL-22) followed by mechanical removal or disruption of the stratum corneum by tape-stripping. (B) The model recapitulates the key phenotypic characteristics of the disease, such as elongation and fusion of the rete ridges, parakeratosis, increased vascularity, and dilated capillaries, among others (hematoxylin-eosin $\times 20$ ). IL indicates interleukin. 
being transplanted to immunodeficient mice, the regenerated human skin will recapitulate the patient's clinical and histologic phenotype. This deconstruction-reconstruction approach has been used successfully to model several rare monogenic hereditary diseases (both recessive and dominant) which have devastating symptoms and outcomes and for which there is currently no effective treatment (Fig. 4). The genodermatoses that have been studied in this way include skin fragility diseases, such as epidermolysis bullosa, ${ }^{28-30}$ in which blistering occurs spontaneously or following minimal trauma, and skin diseases such as xeroderma pigmentosum, in which mutations in DNA repair enzymes make the affected individuals cancer prone. ${ }^{31}$ The model has also been used in the study of genetic diseases affecting proliferation and differentiation patterns, such as pachyonychia congenita $^{32}$ and Netherton syndrome, ${ }^{33}$ respectively. Our team, working with several European groups, has managed to correct cells from patients with some of these conditions using various gene-therapy approaches. ${ }^{33-35}$

Recently, we developed a model of psoriasis, ${ }^{36}$ a highly prevalent disease. In this new humanized model, the incorporation of an immune component into the system has been the key to recreating the classic plaque psoriasis phenotype (Fig. 5). This platform will allow us to continue investigating the roles of the epidermis and the immune system in this very complex skin disease.

\section{Conclusions and Future}

Systems based on bioengineered skin like those described in the present article offer several advantages, such as the ability to grow keratinocytes that retain their functionality, including that of the stem compartment, thanks to the use of a three-dimensional fibrin scaffold that preserves the potency and functionality of the epidermal skin cells. This matrix also ensures the viability of the embedded fibroblasts, which are capable of triggering cell signaling to promote key tissue regeneration processes. The bioengineered skin developed by our group has not only led to the development of a robust preclinical platform for humanized models that are being used to evaluate innovative strategies, such as gene and cell therapies, it also provides a clinically relevant alternative in the field of skin regeneration that can be used in several diseases.

Our aim in the near future is to gain a better understanding of the molecular markers involved in tissue regeneration and repair and to decipher the mechanisms governing epidermal stem cell pluripotency in humans. This knowledge will enable us to model skin diseases that are more complex than those described above and to improve the products derived from tissue engineering in order to develop skin substitutes that can regenerate epidermal appendages, such as hair follicles and sebaceous glands.

\section{Financing}

Our work has been funded by the Spanish Department of Science and Innovation (SAF2007-61019 and SAF 2010-16976), by the Centro de Investigación Biomédica en Red de Enfermedades Raras (CIBERER), and by the Ministry of Health (Advanced Therapies Plan, TRA 0160).

\section{Conflicts of Interest}

The authors declare that they have no conflicts of interest.

\section{Acknowledgements}

We would like to acknowledge the work of our technicians Almudena Holguín, Nuria Illera, Maria Luisa Retamosa, Blanca Duarte, Isabel de los Santos, and Federico Sanchez. We also wish to thank the researchers Marta Carretero, Natividad Cuadrado, Marta García, María José Escámez, and Fernando Larcher for their work and dedication. We also wish to thank Alvaro Meana, Sara Llames and Eva García, our team at the Centro Comunitario de Sangre y Tejidos in Asturias, for their invaluable participation. Thanks are also due to the dermatologists Antonio Torrelo, Ángela Hernández, Raúl de Lucas, and the surgeons Juan Carlos López, Purificación Holguín, Javier Enríquez de Salamanca, Eva López, Sebastián Mir-Mir, and José María Lasso. And finally, we also wish to recognize the contribution of the Spanish associations of patients with epidermolysis bullosa (DEBRA-Spain) and pachyonychia congenita (the International Pachyonychia Congenita Consortium [IPCC]).

The authors of this paper would like to express their sincere gratitude to all the patients and their families, who have taught us so much in recent years. They are the true source of inspiration for our work.

\section{References}

1. Alonso L, Fuchs E. Stem cells of the skin epithelium. Proc Natl Acad Sci USA. 2003;100 Suppl. 1:11830-5.

2. Papini S, Cecchetti D, Campani D, Fitzgerald W, Grivel JC, Chen S, et al. Isolation and clonal analysis of human epidermal keratinocyte stem cells in long-term culture. Stem Cells. 2003;21:481-94.

3. Fuchs E. Skin stem cells: rising to the surface. J Cell Biol. 2008;180:273-84.

4. Guenou H, Nissan X, Larcher F, Feteira J, Lemaitre G, Saidani $M$, et al. Human embryonic stem-cell derivatives for full reconstruction of the pluristratified epidermis: a preclinical study. Lancet. 2009;374:1745-53.

5. Raya A, Rodríguez-Pizà I, Guenechea G, Vassena R, Navarro S, Barrero MJ, et al. Disease-corrected haematopoietic progenitors from Fanconi anaemia induced pluripotent stem cells. Nature. 2009;460:53-9.

6. Pham C, Greenwood J, Cleland H, Woodruff P, Maddern G. Bioengineered skin substitutes for the management of burns: a systematic review. Burns. 2007;33:946-57.

7. Gómez C, Galán JM, Torrero V, Ferreiro I, Pérez D, Palao R, et al. Use of an autologous bioengineered composite skin in extensive burns: clinical and functional outcomes. A multicentric study. Burns. 2011;37:580-9.

8. MacNeil S. Progress and opportunities for tissue-engineered skin. Nature. 2007;445:874-80.

9. Langer R, Vacanti JP. Tissue engineering. Science. 1993;260:920-6.

10. Cuono CB, Langdon R, Birchall N, Barttelbort S, McGuire J. Composite autologous-allogeneic skin replacement: development and clinical application. Plast Reconstr Surg. 1987;80:626-37.

11. Desai MH, Mlakar JM, McCauley RL, Abdullah KM, Rutan RL, Waymack JP, et al. Lack of long-term durability of cultured 
keratinocyte burn-wound coverage: a case report. Burn Care Rehabil. 1991;12:540-5.

12. Gallico Illrd GG. Biologic skin substitutes. Clin Plast Surg. 1990;17:519-26.

13. Llames S, García E, García V, del Río M, Larcher F, Jorcano JL, et al. Clinical results of an autologous engineered skin. Cell Tissue Bank. 2006;7:47-53.

14. Meana A, Iglesias J, Del Río M, Larcher F, Madrigal B, Fresno MF, et al. Large surface of cultured human epithelium obtained on a dermal matrix based on live fibroblast-containing fibrin gels. Burns. 1998;24:621-30.

15. Llames SG, Del Río M, Larcher F, García E, García M, Escamez MJ, et al. Human plasma as a dermal scaffold for the generation of a completely autologous bioengineered skin. Transplantation. 2004;77:350-5.

16. Geer DJ, Swartz DD, Andreadis ST. Fibrin promotes migration in a three-dimensional in vitro model of wound regeneration. Tissue Eng. 2002;8:787-98.

17. Helary C, Abed A, Mosser G, Louedec L, Meddahi-Pellé A, Giraud-Guille MM. Synthesis and in vivo integration of improved concentrated collagen hydrogels. J Tissue Eng Regen Med. 2011;5:248-52.

18. Carretero M, Escamez MJ, Prada F, Mirones I, García M, Holguin $A$, et al. Skin gene therapy for acquired and inherited disorders. Histol Histopathol. 2006;21:1233-47.

19. Camblor-Santervás L, Meana-Infiesta A, Llaneza-Coto JM, Vaquero-Lorenzo F, Gómez-Llames S, López-García D, et al. Tratamiento de úlceras vasculares crónicas con equivalentes cutáneos obtenidos mediante ingeniería tisular. Angiologia. 2003;01:21-33.

20. Eisenbud DE, Huang NF, Luke S, Silberklang M. Bio-engineered skin substitutes: current status and challenges. Wounds. 2004;16:2-17.

21. Del Río M, Larcher F, Serrano F, Meana A, Muñoz M, García M, et al. A pre-clinical model for the analysis of human genetically modified skin in vivo. Hum Gene Ther. 2002;13:959-68.

22. Larcher F, Dellambra E, Rico L, Bondanza S, Murillas R, Cattoglio $C$, et al. Long-term engraftment of single genetically modified human epidermal holoclones enables safety pre-assessment of cutaneous gene therapy. Mol Ther. 2007;15:1670-6.

23. García M, Escamez MJ, Carretero M, Mirones I, MartínezSantamaría L, Navarro $M$, et al. Modeling normal and pathological processes through skin tissue engineering. Mol Carcinog. 2007;46:741-5.

24. Escamez MJ, Garcia M, Larcher F, Meana A, Munoz E, Jorcano JL, et al. An in vivo model of wound healing in genetically modified skin-humanized mice. J Invest Dermatol. 2004;123:1182-91.

25. Escámez MJ, Carretero M, García M, Martínez-Santamaría L, Mirones I, Duarte B, et al. Assessment of optimal virus-mediated growth factor gene delivery for human cutaneous wound healing enhancement. J Invest Dermatol. 2008;128:1565-75.

26. Escámez MJ, Carretero M, García M, Martínez-Santamaría L, Larcher F, Del Río M. Smart growth factor gene delivery for impaired wound healing. In: Chandan KS, editor. Wound healing society year book, vol. 1: advances in wound care. EE, UU: Mary Ann Liebert Inc.; 2010. p. 367-74.

27. Carretero M, Escámez M, García M, Mirones I, Larcher F, Río M. La terapia génica cutánea como estrategia de intervención en la dermatología. In: Ascencio González D, editor. Medicina regenerativa e ingeniería tisular. Del laboratorio a la clínica. México: Editorial Alfil; 2009. p. 147-66.

28. Escámez M, Carretero M, García M, Meana A, Larcher F, Del Río M. Terapia génica y celular como estrategias de intervención en enfermedades dermatológicas huérfanas. In: Kaminsky A, Mascaró JM, editors. Monografías de Dermatología: Enfermedades huérfanas I. Madrid: Aula médica Ediciones; 2009. p. 69-77.

29. Siañez-González C, Pezoa-Jares R, Salas-Alanis JC. Epidermólisis ampollosa congénita: revisión del tema. Actas Dermosifiliogr. 2009;100:842-56.

30. Hernández-Martín A, Torrelo A. Epidermólisis ampollosas hereditarias: del diagnóstico a la realidad. Actas Dermosifiliogr. 2010;101:495-505.

31. García M, Llames S, García E, Meana A, Cuadrado N, Recasens M, et al. In vivo assessment of acute UVB responses in normal and Xeroderma Pigmentosum (XP-C) skin-humanized mouse models. Am J Pathol. 2010;177:865-72.

32. García M, Larcher F, Hickerson RP, Baselga E, Leachman SA, Kaspar RL, et al. Development of skin-humanized mouse models of Pachyonychia Congenita. J Invest Dermatol. 2011;131:1053-60.

33. Di WL, Larcher F, Semenova E, Talbot GE, Harper JI, Del Río M, et al. Ex vivo gene therapy restores LEKTI activity and corrects the architecture of Netherton syndrome-derived skin grafts. Mol Ther. 2011;19:408-16.

34. Gache Y, Baldeschi C, Del Río M, Gagnoux-Palacios L, Larcher F, Lacour JP, et al. Construction of skin equivalents for gene therapy of recessive dystrophic epidermolysis bullosa. Hum Gene Ther. 2004;15:921-33.

35. Spirito F, Capt A, Del Rio M, Larcher F, Guaguere E, Danos 0 , et al. Sustained phenotypic reversion of junctional epidermolysis bullosa dog keratinocytes: establishment of an immunocompetent animal model for cutaneous gene therapy. Biochem Biophys Res Commun. 2006;339:769-78.

36. Guerrero-Aspizua S, García M, Murillas R, Retamosa L, Illera N, Duarte B, et al. Development of a bioengineered skin-humanized mouse model for psoriasis: dissecting epidermal-lymphocyte interacting pathways. Am J Pathol. 2010;177:3112-24. 